Published in final edited form as:

J Med Virol. 2016 November ; 88(11): 1837-1843. doi:10.1002/jmv.24559.

\title{
Recent Advances in Understanding Norovirus Pathogenesis
}

\author{
Stephanie M. Karst ${ }^{\star}$ and Scott A. Tibbetts \\ Department of Molecular Genetics and Microbiology, College of Medicine, Emerging Pathogens \\ Institute, University of Florida, Gainesville, Florida
}

\begin{abstract}
Noroviruses constitute a family of ubiquitous and highly efficient human pathogens. In spite of decades of dedicated research, human noroviruses remain a major cause of gastroenteritis and severe diarrheal disease around the world. Recent findings have begun to unravel the complex mechanisms that regulate norovirus pathogenesis and persistent infection, including the important interplay between the virus, the host immune system, and commensal bacteria. Herein, we will summarize recent research developments regarding norovirus cell tropism, the use of $\mathrm{M}$ cells, and commensal bacteria to facilitate norovirus infection, and virus, host, and bacterial determinants of persistent norovirus infections.
\end{abstract}

\section{Keywords}

digestive system; cell cultures; model organisms

\section{INTRODUCTION}

Noroviruses comprised a genetically diverse group of nonenveloped plus-strand RNA viruses that infect many host species and are enteric in nature. In particular, human noroviruses are a major cause of gastroenteritis outbreaks and sporadic diarrhea across the globe. They are the leading cause of foodborne disease globally [Koo et al., 2010] and the leading cause of severe childhood diarrhea in parts of the world where a rotavirus vaccination program is being implemented [Koo et al., 2013; Payne et al., 2013; BeckerDreps et al., 2014]. A recent systematic review of diarrheal epidemiology studies reveals that noroviruses are responsible for nearly $20 \%$ of all cases of acute gastroenteritis [Ahmed et al., 2014], and increased reporting over recent years has led to the realization that they are the most common cause of acute gastroenteritis outbreaks in the United States [Wikswo et al., 2015]. It is also becoming increasingly appreciated that human norovirus infections are common in immunocompromised and transplant patients where they can lead to lifethreatening dehydration [Bok and Green, 2012; Green, 2014].

Human volunteer studies have been instrumental to studying various aspects of norovirus pathogenesis and immunity. For example, two small-scale clinical trials have demonstrated that norovirus virus-like particle (VLP) immunization provides modest protection from

\footnotetext{
*Correspondence to: Stephanie M. Karst, Department of Molecular Genetics and Microbiology, College of Medicine, Emerging Pathogens Institute, University of Florida, 1200 Newell Dr., R2-293, Gainesville, FL 32610. skarst@ufl.edu.
} 
severe disease in challenged volunteers [Atmar et al., 2011; Bernstein et al., 2015] and has facilitated the study of norovirus antibody responses [e.g., Swanstrom et al., 2013; Atmar et al., 2015; Lindesmith et al., 2015]. Nevertheless, such studies are limited by the inherent issues of utilizing human volunteers including an inability to perform infections in specific genetic and microbial deficiencies, an inability to obtain tissue samples throughout the course of infection, and substantial financial constraints.

Because of their genetic and environmental manipulability, animal models of infection are also vital to advance our understanding of pathogen-host interactions. There are a variety of small and large animal models of norovirus infection, each with unique benefits and challenges [reviewed in Karst et al., 2014]. Gnotobiotic piglets, gnotobiotic calves, chimpanzees, and immunocompromised mice are all variably susceptible to human noroviruses, with piglets and calves developing mild diarrhea and chimps and mice asymptomatically infected [Wyatt et al., 1978; Cheetham et al., 2006; Souza et al., 2008; Bok et al., 2011; Taube et al., 2013]. The most widely studied animal model of norovirus infection is the murine norovirus system which facilitates investigation of a norovirus in its natural host species. Since the discovery of the first murine norovirus in 2003 [Karst et al., 2003] and the subsequent identification of numerous genetically related viral isolates from geographically diverse locations [e.g., Hsu et al., 2006; Thackray et al., 2007], this research platform has become widely used in the field and has recently provided a number of groundbreaking observations into norovirus pathogenesis and mucosal immunity. Although murine norovirus infection of wild-type mice does not cause overt gastroenteritis, infection of mice lacking functional interferon (IFN) signaling pathways results in severe diarrhea, gastric bloating, weight loss, and systemic disease [Karst et al., 2003; Mumphrey et al., 2007]. Moreover, infection of both wild-type and IFN signaling-deficient mice shares many pathogenic and immunologic features with human norovirus infection including fecal-oral transmission, prolonged shedding, and suboptimal induction of protective immunity.

Despite the utility of animal models, a significant obstacle for the field has been the lack of any cell culture system for human noroviruses. Thus, research tools to study host-norovirus interactions have historically been very limited. However, there has been a recent explosion of research in this area that has provided fascinating surprises, and in some cases has challenged long-held views of norovirus pathogenesis. For example, while there was a general belief that noroviruses preferentially infect the upper small intestine, studies in the murine norovirus model system firmly support the establishment of persistent infection in the colons of mice. In this review, we will summarize recent findings pertaining to norovirus-host interactions along the intestinal tract, including: (i) norovirus cell tropism; (ii) viral strategies facilitating infection of the intestinal tract; (iii) the discovery that commensal bacteria stimulate norovirus infection of the intestine; and (iv) mechanisms contributing to viral persistence establishment along the intestinal tract. While there has also been tremendous progress in other aspects of norovirus biology, including norovirus immunity [Newman and Leon, 2015; Pringle et al., 2015; Roth and Karst, 2016], replication mechanisms [Thorne and Goodfellow, 2013], and glycan interactions [Ruvoën-Clouet et al., 2013; Venkataram Prasad et al., 2014], comprehensive and recent reviews on these topics are available and thus will not be covered here. 


\section{Noroviruses Likely Infect Both Intestinal Immune Cells and Enterocytes}

The precise cell tropism of noroviruses has long confounded the research community because of the enormous challenges in culturing human noroviruses. Recent in vitro and in vivo advances in the field have begun to overcome this challenge and cumulatively reveal infection of both immune cells and enterocytes (Table I). It is now well-established that murine noroviruses efficiently infect immune cells, including cultured macrophages, dendritic cells, and B cells [Wobus et al., 2004; Jones et al., 2014]. In agreement with this, the GII.4-Sydney human norovirus strain infects B cells [Jones et al., 2014, 2015; Karst, 2015] in culture although efforts to infect macrophages and dendritic cells with a human norovirus have thus far been unsuccessful [Lay et al., 2010]. Notably, human norovirus infection of B cells is facilitated by a co-factor derived from commensal bacteria [Jones et al., 2014; Karst, 2015], a strategy shared by a growing list of enteric viruses (described below). Interestingly, the nature of norovirus replication in B cells is distinct from that of macrophage/dendritic cells in that neither human nor murine norovirus infection of B cells results in overt cytopathic effect (CPE), whereas murine norovirus infection of macrophages and dendritic cells results in cell lysis [Jones et al., 2014; Karst, 2015]. Consistent with this finding, B cells (but not macrophages or dendritic cells) become persistently infected with murine noroviruses in culture [Jones et al., 2014; Karst, 2015]. These observations are quite surprising considering that noroviruses are nonenveloped, thus they are presumed to require cell lysis for release of progeny virions in contrast to enveloped viruses which can egress via budding at intracellular or plasma membranes.

Several lines of evidence confirm norovirus tropism for immune cells in vivo. Viral antigen was detected in mononuclear lamina propria cells of an intestinal biopsy obtained from a human norovirus-infected volunteer [Lay et al., 2010]. Likewise, human norovirus-infected chimpanzees demonstrated virus-positive dendritic cells and B cells in the duodenum [Bok et al., 2011], human norovirus-infected gnotobiotic calves contained antigen-positive cells resembling macrophages in the intestinal lamina propria [Souza et al., 2008], and human norovirus-infected immunocompromised mice contained antigen-positive cells in the spleen and liver that morphologically resembled macrophages [Taube et al., 2013]. Similarly, murine norovirus antigen can be detected in macrophages, dendritic cells, and Peyer's patch B cells of infected mice [Wobus et al., 2004; Ward et al., 2006; Mumphrey et al., 2007; Perdue et al., 2007; Jones et al., 2014].

Further supporting the importance of immune cell tropism for efficient norovirus infection in vivo, a recent comparison of human norovirus loads in the feces of severely immunocompromised children revealed 1-log lower viral loads in patients lacking B cells compared to those with B cells [Brown et al., 2016]. In agreement with this, mice deficient in dendritic cells or B cells display reduced murine norovirus titers along the intestinal tract [Elftman et al., 2013; Zhu et al., 2013; Jones et al., 2014]. In addition, as is the case for several other important pathogens, dendritic cells have been implicated as critical mediators of murine norovirus dissemination to secondary lymphoid tissues [Elftman et al., 2013]. Finally, a recent in vivo murine norovirus study reveals a correlation between the efficiency of B cell infection and the extent of virulence [Zhu et al., 2015]. These collective in vitro and in vivo data prove conclusively that noroviruses can infect both innate (macrophages 
and dendritic cells) and adaptive (B cells) immune cells along the intestinal tract, and suggest that infection of these cell types is a crucial determinant of viral pathogenesis.

Considering that noroviruses enter their hosts in the gut lumen, they must possess a mechanism to breach the single layer of intestinal epithelial cells, or enterocytes, that line the gut wall in order to access underlying immune cells. Although extensive efforts to infect standard epithelial cell lines with noroviruses in culture have thus far been unsuccessful [Duizer et al., 2004; Basic et al., 2014; Jones et al., 2014], there is in vivo support for enterocyte infection. Murine norovirus antigen could be detected in enterocytes following infection of IFN-deficient mice [Mumphrey et al., 2007], and virus antigen-positive enterocytes were observed in gnotobiotic piglets and calves infected with a human norovirus [Cheetham et al., 2006; Souza et al., 2008].

Available data from animal models suggest that norovirus cell tropism is regulated in vivo by yet-to-be-defined factors. For example, while human norovirus antigen was detected in enterocytes of gnotobiotic piglets and calves [Cheetham et al., 2006; Souza et al., 2008], viral antigen was exclusively detected in immune cells in human norovirus-infected chimpanzees, mice, and a human biopsy sample [Lay et al., 2010; Bok et al., 2011; Taube et al., 2013]. Considering the newly appreciated interaction between noroviruses and commensal bacteria (described below), these seemingly contradictory results could conceivably be explained by microbial regulation of viral tropism; or alternatively, by species-dependent cell tropism, temporal distinctions in cell tropism, virus strain differences, or immunological regulation. Supporting the latter possibility, murine norovirus infection of enterocytes has only been observed in IFN-deficient hosts, whereas immune cells are infected in immunocompetent hosts [Mumphrey et al., 2007]. In conclusion, noroviruses can infect a variety of cell types including macrophages, dendritic cells, B cells, and enterocytes. An exciting area of future research will be to identify host, environmental, and viral factors that regulate norovirus cell tropism along the intestinal tract during natural infections.

\section{Noroviruses Can Exploit M Cells to Cross the Intestinal Epithelial Barrier}

Enterocytes are equipped to sample material from the gut lumen and transfer it to underlying immune cells for effective induction of tolerogenic and inflammatory responses. A specialized subset of enterocytes called microfold cells ( $\mathrm{M}$ cells) are particularly important in this process. M cells in the gut lumen overlie Peyer's patches and isolated lymphoid follicles. While they lack microvilli on their apical membrane and do not secrete mucus, $\mathrm{M}$ cells are highly efficient at sampling and transporting luminal material to the underlying immune aggregates [Mabbott et al., 2013]. Numerous types of pathogens have evolved strategies to take advantage of the sampling property and use $\mathrm{M}$ cells as portals to breach the intestinal epithelium [Mabbott et al., 2013]. Accumulating evidence supports the notion that noroviruses also exploit $\mathrm{M}$ cells. First, even in the absence of viral replication, both human and murine noroviruses can be apically internalized by confluent monolayers of enterocytes and then released basally [Marionneau et al., 2002; Gonzalez-Hernandez et al., 2013]. Importantly, released virus remains competent for productive infection of underlying immune cells in the basal chamber [Gonzalez-Hernandez et al., 2013; Jones et al., 2014, 2015]. Furthermore, recent findings reveal that murine noroviruses require Peyer's patches 
and $\mathrm{M}$ cells for efficient oral infection [Gonzalez-Hernandez et al., 2014; Kolawole et al., 2015]. Thus, these data collectively support a model whereby noroviruses are transported across $\mathrm{M}$ cells to access underlying target immune cells, as reviewed in [Karst and Wobus, 2015].

\section{Noroviruses Require Commensal Bacteria for Efficient Intestinal Infection}

In a series of recent studies, it has become well-established that enteric virus infections, including poliovirus, reovirus, rotavirus, mouse mammary tumor virus, and norovirus, are enhanced by interactions with commensal bacteria [Kane et al., 2011; Kuss et al., 2011; Jones et al., 2014; Kernbauer et al., 2014; Robinson et al., 2014; Uchiyama et al., 2014; Baldridge et al., 2015; Wilks et al., 2015]. In the first direct demonstration that commensal bacterial enhance norovirus infection, it was revealed that human norovirus infection of cultured B cells was facilitated by commensal bacteria [Jones et al., 2014; Karst, 2015]. Filtration of commensal bacteria from virus-positive stool samples substantially reduced viral infectivity of B cells, and infectivity could be completely restored by incubating filtered inoculum with commensal bacteria expressing the H-type histo-blood group antigen (HBGA). Validating a role for commensal bacteria in stimulating norovirus infections in vivo, antibiotic-mediated depletion of the intestinal microbiota of mice significantly reduces the level of murine norovirus replication along the intestinal tract [Jones et al., 2014; Baldridge et al., 2015]. Consistent with this, germ-free mice support reduced norovirus replication compared to microbially colonized mice [Kernbauer et al., 2014]. The stimulatory role played by commensal bacteria is specific to intestinal infection since viral replication is unaffected by oral antibiotic treatment if virus is inoculated intraperitoneally instead of orally [Baldridge et al., 2015].

The basis of bacterial stimulation of norovirus infection may be multifactorial, including both direct and indirect mechanisms [Karst, 2016]. Supporting direct stimulation, HBGA enhances human norovirus attachment to permissive B cells [Jones et al., 2014]. Additional lines of evidence also support the involvement of indirect stimulation in the form of immunoregulation. First, although murine norovirus infection is noninflammatory in microbially colonized wild-type mice, it induces modest inflammation in mice lacking the immunosuppressive cytokine IL-10 and this phenotype is dependent on commensal bacteria [Basic et al., 2014]. Second, evidence indicates that commensal bacteria suppress the antiviral activity of type III IFN to facilitate persistent murine norovirus infection in the colon [Baldridge et al., 2015]. Uncovering the specific interactions of noroviruses and commensal bacteria as well as the physiological relevance of these interactions will undoubtedly be a rich area of investigation in years to come.

\section{Noroviruses Establish Persistent Infections}

Although symptoms resulting from human norovirus infections resolve rapidly, people continue to shed virus in their stool for protracted periods [Patterson et al., 1993; Rockx et al., 2002; Murata et al., 2007]. In fact, asymptomatically infected people can shed virus for up to 60 days, an amount of time comparable to that of people exhibiting typical symptomology [Teunis et al., 2015; Costantini et al., 2015], and immunocompromised 
patients can shed virus chronically for months and even years [Green, 2014]. These data suggest an intra-host reservoir of prolonged norovirus replication that occurs irrespective of symptomatic infection and could be a major contributing factor to viral maintenance in the human population. The data also imply that noroviruses encode mechanisms to antagonize or evade host immunity, a conclusion that is strongly supported by both in vitro and in vivo data, as reviewed in [Roth and Karst, 2016]. Consistent with prolonged norovirus shedding in humans, chimpanzees infected with a human norovirus display prolonged fecal shedding [Bok et al., 2011], and mice infected with murine noroviruses demonstrate chronic fecal shedding that is associated with persistent infection of the colon [Hsu et al., 2006; Thackray et al., 2007; Arias et al., 2012]. The availability of the highly tractable murine model has begun to shed light on specific host, virus, and microbiota determinants of norovirus persistence. Recent work demonstrates that the establishment of persistent murine norovirus infection correlates with a suboptimal antiviral CD8 T cell response [Tomov et al., 2013]. While both acute (MNV-1.CW3) and persistent (MNV-CR6) murine norovirus strains induce short-term upregulation of crucial mucosal homing receptors on intestinal virus-specific CD8 T cells, upregulation is not maintained following infection with persistent strain MNVCR6. Similarly, while acute strain MNV-1.CW3 induced a polyfunctional CD8 T cell effector response (IFN- $\gamma$, TNF- $a$, MIP-1a, and granzyme B [GZM-B]), the chronic strain MNV-CR6 induced a more restricted response (MIP-1a or GZM-B) [Tomov et al., 2013]. Overall, these data suggest that the ability of individual norovirus strains to induce distinct antiviral $\mathrm{T}$ cell responses contributes to the determination of their fate as acute or persistent infections.

The direct comparison of acute (e.g., MNV-1) and persistent (e.g., MNV-3, MNV-CR6, MNV-CR3) murine norovirus strains and the availability of a murine norovirus reverse genetics system has enabled the identification of some viral determinants of persistence establishment. For example, a single glutamic acid at position 94 in the $5^{\prime}$ domain of the nonstructural protein NS1/2 is sufficient to enhance MNV-1 replication and persistence in the colon. This residue, D94, which is conserved in all persistent murine norovirus strains identified to date [Nice et al., 2013], regulates the tertiary structure of the protein [Borin et al., 2013]. Notably, the human norovirus NS1/2 protein colocalizes with Golgi markers and impairs host protein secretory pathways in transfection experiments [Ettayebi and Hardy, 2003; Fernandez-Vega et al., 2004]. Thus, it is conceivable that NS1/2 inhibits cytokine secretion or antigen presentation, and therefore impairs the development of immune responses required for viral clearance [Sharp and Estes, 2010; Roth and Karst, 2016]. Finally, at least one report has suggested that the genome-scale ordered RNA secondary structure (GORS) of noroviruses may also regulate persistence; although recombinant murine noroviruses with synonymous disruptions of RNA secondary structure replicated to wild-type levels in cultured cells and could establish persistence, these genomes were outcompeted by wild-type virus [McFadden et al., 2013].

In addition to these potential host and viral determinants of persistence, a recent study revealed that commensal bacteria can regulate the establishment of persistent norovirus infections. Remarkably, antibiotic-mediated depletion of commensal bacteria prevented MNV-CR6 from establishing chronic infection in the colons of infected mice, but MNV-CR6 persistence could be rescued by restoring the intestinal microbiota via fecal transplantation 
[Baldridge et al., 2015]. Importantly, commensal bacteria were not required for establishment of persistence in mice lacking type III IFN (IFN- $\lambda$ ) responses. Cumulatively, these findings support a model whereby commensal bacteria facilitate persistent norovirus infections by suppressing antiviral IFN- $\lambda$ [Baldridge et al., 2015]. This intriguing example highlights how the complex interplay between immunologic, viral, and microbial determinants regulates the ability of noroviruses to establish persistence in the colon, and thus to be shed in feces for protracted periods of time even in immunocompetent hosts.

\section{CONCLUSIONS}

Recent developments in norovirus research have shed new light on the multifaceted interactions between these viruses, the host immune system, and commensal bacteria that govern norovirus pathogenesis and persistence. Following on decades of historical norovirus research, these current findings represent a multifactorial approach in which human norovirus infection systems, modern viral genetics, and animal model systems have all played an important role. This cumulative work supports the concept that noroviruses exploit the evolutionary balance between commensal bacteria and the immune system to facilitate infection of immune cells that underlie the gastric lumen. Transport by $\mathrm{M}$ cells across the epithelial barrier, and infection of enterocytes themselves, likely also play key roles in this process. Although the further development of in vitro culture systems that are both facile and highly robust remain a major goal for in vitro studies, the availability of a new culture system is very exciting for a field long-hindered by the inability to propagate the human viruses, and should facilitate a deeper understanding of viral replication mechanisms and virus-cell interactions. In the future it will be critical to continue to use both clinical specimens and in vivo models to assess the likely interrelationship of enterocyte and immune cell infection, and the impact of immunological and environmental factors on virus replication and tropism. While these have historically been very difficult pathogens to study, recent developments in virology, mucosal immunity, and microbiota research have led to a deeper understanding of norovirus infections and pathogenesis. Understanding the relationships between these key factors should open up novel strategies for reducing population spread of these ubiquitous viruses.

\section{Acknowledgments}

Grant sponsor: NIH; Grant number: 1R01AI116892

\section{REFERENCES}

Ahmed SM, Hall AJ, Robinson AE, Verhoef L, Premkumar P, Parashar UD, Koopmans M, Lopman BA. Global prevalence of norovirus in cases of gastroenteritis: A systematic review and metaanalysis. Lancet Infect Dis. 2014; 14:725-730. [PubMed: 24981041]

Arias A, Bailey D, Chaudhry Y, Goodfellow IG. Development of a reverse genetics system for murine norovirus 3; long-term persistence occurs in the caecum and colon. J Gen Virol. 2012; 93:14321441. [PubMed: 22495235]

Atmar RL, Bernstein DI, Harro CD, Al-Ibrahim MS, Chen WH, Ferreira J, Estes MK, Graham DY, Opekun AR, Richardson C, Mendelman PM. Norovirus vaccine against experimental human Norwalk virus illness. N Engl J Med. 2011; 365:2178-2187. [PubMed: 22150036] 
Atmar RL, Bernstein DI, Lyon GM, Treanor JJ, Al-Ibrahim MS, Graham DY, Vinjé J, Jiang X, Gregoricus N, Frenck RW, Moe CL, Chen WH, Ferreira J, Barrett J, Opekun AR, Estes MK, Borkowski A, Baehner F, Goodwin R, Edmonds A, Mendelman PM. Serological correlates of protection against a GII.4 norovirus. Clin Vaccine Immunol. 2015; 22:923-929. [PubMed: 26041041]

Baldridge MT, Nice TJ, McCune BT, Yokoyama CC, Kambal A, Wheadon M, Diamond MS, Ivanova Y, Artyomov M, Virgin HW. Commensal microbes and interferon- $\lambda$ determine persistence of enteric murine norovirus infection. Science. 2015; 347:266-269. [PubMed: 25431490]

Basic M, Keubler LM, Buettner M, Achard M, Breves G, Schröder B, Smoczek A, Jörns A, Wedekind D, Zschemisch NH, Gunther C, Neumann D, Lienenklaus S, Weiss S, Hornef MW, Mahler M, Bleich A. Norovirus triggered microbiota-driven mucosal inflammation in interleukin 10-deficient mice. Inflamm Bowel Dis. 2014; 20:431-443. [PubMed: 24487272]

Becker-Dreps S, Bucardo F, Vilchez S, Zambrana LE, Liu L, Weber DJ, Peña R, Barclay L, Vinjé J, Hudgens MG, Nordgren J, Svensson L, Morgan DR, Espinoza F, Paniagua M. Etiology of childhood diarrhea after rotavirus vaccine introduction: A prospective, population-based study in Nicaragua. Pediatr Infect Dis J. 2014; 33:1156-1163. [PubMed: 24879131]

Bernstein DI, Atmar RL, Lyon GM, Treanor JJ, Chen WH, Jiang X, Vinjé J, Gregoricus N, Frenck RW, Moe CL, Al-Ibrahim MS, Barrett J, Ferreira J, Estes MK, Graham DY, Goodwin R, Borkowski A, Clemens R, Mendelman PM. Norovirus vaccine against experimental human GII.4 virus illness: A challenge study in healthy adults. J Infect Dis. 2015; 211:870-878. [PubMed: 25210140]

Bok K, Green KY. Norovirus gastroenteritis in immunocompromised patients. N Engl J Med. 2012; 367:2126-2132. [PubMed: 23190223]

Bok K, Parra GI, Mitra T, Abente E, Shaver CK, Boon D, Engle R, Yu C, Kapikian AZ, Sosnovtsev SV, Purcell RH, Green KY. Chimpanzees as an animal model for human norovirus infection and vaccine development. Proc Natl Acad Sci. 2011; 108:325-330. [PubMed: 21173246]

Borin BN, Tang W, Nice TJ, McCune BT, Virgin HW, Krezel AM. Murine norovirus protein NS1/2 aspartate to glutamate mutation sufficient for persistence reorients sidechain of surface exposed tryptophan within a novel structured domain. Proteins. 2013; 82:1200-1209. [PubMed: 24273131]

Brown JR, Gilmour K, Breuer J. Norovirus infections occur in B-cell-deficient patients. Clin Infect Dis. 2016; 62:1136-1138. [PubMed: 26908782]

Cheetham S, Souza M, Meulia T, Grimes S, Han MG, Saif LJ. Pathogenesis of a genogroup II human norovirus in gnotobiotic pigs. J Virol. 2006; 80:10372-10381. [PubMed: 17041218]

Costantini VP, Cooper EM, Hardaker HL, Lee LE, Bierhoff M, Biggs C, Cieslak PR, Hall AJ, Vinjé J. Epidemiologic, virologic, and host genetic factors of norovirus outbreaks in long-term care facilities. Clin Infect Dis. 2015:civ747.

Duizer E, Schwab KJ, Neill FH, Atmar RL, Koopmans MPG, Estes MK. Laboratory efforts to cultivate noroviruses. J Gen Virol. 2004; 85:79-87. [PubMed: 14718622]

Elftman MD, Gonzalez-Hernandez MB, Kamada N, Perkins C, Henderson KS, Nunez G, Wobus CE. Multiple effects of dendritic cell depletion on murine norovirus infection. J Gen Virol. 2013; 94:1761-1768. [PubMed: 23636823]

Ettayebi K, Hardy ME. Norwalk virus nonstructural protein $\mathrm{p} 48$ forms a complex with the SNARE regulator VAP-A and prevents cell surface expression of vesicular stomatitis virus G protein. J Virol. 2003; 77:11790-11797. [PubMed: 14557663]

Fernandez-Vega V, Sosnovtsev SV, Belliot G, King AD, Mitra T, Gorbalenya A, Green KY. Norwalk virus $\mathrm{N}$-terminal nonstructural protein is associated with disassembly of the golgi complex in transfected cells. J Virol. 2004; 78:4827-4837. [PubMed: 15078964]

Gonzalez-Hernandez MB, Liu T, Blanco LP, Auble H, Payne HC, Wobus CE. Murine norovirus transcytosis across an In vitro polarized murine intestinal epithelial monolayer is mediated by Mlike cells. J Virol. 2013; 87:12685-12693. [PubMed: 24049163]

Gonzalez-Hernandez MB, Liu T, Payne HC, Stencel-Baerenwald J, Ikizler M, Yagita H, Dermody TS, Williams IR, Wobus CE. Efficient norovirus and reovirus replication in the mouse intestine requires microfold (M) cells. J Virol JVI. 2014; 88:6934-6943.

Green KY. Norovirus infection in immunocompromised hosts. Clin Microbiol Infect. 2014; 20:717723. [PubMed: 25040790] 
Hsu CC, Riley LK, Wills HM, Livingston RS. Persistent infection with and serologic crossreactivity of three novel murine noroviruses. Comp Med. 2006; 56:247-251. [PubMed: 16941951]

Jones MK, Watanabe M, Zhu S, Graves CL, Keyes LR, Grau KR, Gonzalez-Hernandez MB, Iovine NM, Wobus CE, Vinjé J, Tibbetts SA, Wallet SM, Karst SM. Enteric bacteria promote human and murine norovirus infection of B cells. Science. 2014; 346:755-759. [PubMed: 25378626]

Jones MK, Grau KR, Costantini V, Kolawole AO, de Graaf M, Freiden P, Graves CL, Koopmans M, Wallet SM, Tibbetts SA, Schultz-Cherry S, Wobus CE, Vinje J, Karst SM. Human norovirus culture in B cells. Nat Protoc. 2015; 10:1939-1947. [PubMed: 26513671]

Kane M, Case LK, Kopaskie K, Kozlova A, MacDearmid C, Chervonsky AV, Golovkina TV. Successful transmission of a retrovirus depends on the commensal microbiota. Science. 2011; 334:245-249. [PubMed: 21998394]

Karst SM. Identification of a novel cellular target and a cofactor for norovirus Infection-B cells \& commensal bacteria. Gut Microbes. 2015; 6:266-271. [PubMed: 25997033]

Karst SM. Virus-bacteria interactions in the gut. Nat Rev Microbiol. 2016; 14:197-204. [PubMed: 26853118]

Karst SM, Wobus CE. A working model of how noroviruses infect the intestine. PLoS Pathog. 2015; 11:e1004626. [PubMed: 25723501]

Karst SM, Wobus CE, Lay M, Davidson J, Virgin HW. STAT1-dependent innate immunity to a Norwalk-like virus. Science. 2003; 299:1575-1578. [PubMed: 12624267]

Karst SM, Wobus CE, Goodfellow IG, Green KY, Virgin HW. Advances in norovirus biology. Cell Host Microbe. 2014; 15:668-680. [PubMed: 24922570]

Kernbauer E, Ding Y, Cadwell K. An enteric virus can replace the beneficial function of commensal bacteria. Nature. 2014; 516:94-98. [PubMed: 25409145]

Kolawole AO, Gonzalez-Hernandez MB, Turula H, Yu C, Elftman MD, Wobus CE. Oral norovirus infection is blocked in mice lacking Peyer's patches and mature M cells. J Virol. 2015; 90:14991506. [PubMed: 26581993]

Koo HL, Ajami N, Atmar RL, DuPont HL. Noroviruses: The principal cause of foodborne disease worldwide. Discov Med. 2010; 10:61-70. [PubMed: 20670600]

Koo HL, Neill FH, Estes MK, Munoz FM, Cameron A, Dupont HL, Atmar RL. Noroviruses: The most common pediatric viral enteric pathogen at a large university hospital after introduction of rotavirus vaccination. J Pediatr Infect Dis Soc. 2013; 2:57-60.

Kuss SK, Best GT, Etheredge CA, Pruijssers AJ, Frierson JM, Hooper LV, Dermody TS, Pfeiffer JK. Intestinal microbiota promote enteric virus replication and systemic pathogenesis. Science. 2011; 334:249-252. [PubMed: 21998395]

Lay MK, Atmar RL, Guix S, Bharadwaj U, He H, Neill FH, Sastry KJ, Yao Q, Estes MK. Norwalk virus does not replicate in human macrophages or dendritic cells derived from the peripheral blood of susceptible humans. Virology. 2010; 406:1-11. [PubMed: 20667573]

Lindesmith LC, Ferris MT, Mullan CW, Ferreira J, Debbink K, Swanstrom J, Richardson C, Goodwin RR, Baehner F, Mendelman PM, Bargatze RF, Baric RS. Broad blockade antibody responses in human volunteers after immunization with a multivalent norovirus VLP candidate vaccine: Immunological analyses from a phase I clinical trial. PLoS Med. 2015; 12:e1001807. [PubMed: 25803642]

Mabbott NA, Donaldson DS, Ohno H, Williams IR, Mahajan A. Microfold (M) cells: Important immunosurveillance posts in the intestinal epithelium. Mucosal Immunol. 2013; 6:666-677. [PubMed: 23695511]

Marionneau S, Ruvoën N, Le Moullac-Vaidye B, Clement M, Cailleau-Thomas A, Ruiz-Palacois G, Huang P, Jiang X, Le Pendu J. Norwalk virus binds to histo-blood group antigens present on gastroduodenal epithelial cells of secretor individuals. Gastroenterology. 2002; 122:1967-1977. [PubMed: 12055602]

McFadden N, Arias A, Dry I, Bailey D, Witteveldt J, Evans DJ, Goodfellow I, Simmonds P. Influence of genome-scale RNA structure disruption on the replication of murine norovirus-Similar replication kinetics in cell culture but attenuation of viral fitness in vivo. Nucleic Acids Res. 2013; 41:6316-6331. [PubMed: 23630317] 
Mumphrey SM, Changotra H, Moore TN, Heimann-Nichols ER, Wobus CE, Reilly MJ, Moghadamfalahi M, Shukla D, Karst SM. Murine norovirus 1 infection is associated with histopathological changes in immunocompetent hosts, but clinical disease is prevented by STAT1dependent interferon responses. J Virol. 2007; 81:3251-3263. [PubMed: 17229692]

Murata T, Katsushima N, Mizuta K, Muraki Y, Hongo S, Matsuzaki Y. Prolonged norovirus shedding in infants under 6 months of age with gastroenteritis. Pediatr Infect Dis J. 2007; 26:46-49. [PubMed: 17195705]

Newman KL, Leon JS. Norovirus immunology: Of mice and mechanisms. Eur J Immunol. 2015; 45:2742-2757. [PubMed: 26256101]

Nice TJ, Strong DW, McCune BT, Pohl CS, Virgin HW. A single-amino-acid change in murine norovirus NS1/2 is sufficient for colonic tropism and persistence. J Virol. 2013; 87:327-334. [PubMed: 23077309]

Patterson T, Hutchings P, Palmer S. Outbreak of SRSV gastroenteritis at an international conference traced to food handled by a post-symptomatic caterer. Epidemiol Infect. 1993; 111:157-162. [PubMed: 8394241]

Payne DC, Vinjé J, Szilagyi PG, Edwards KM, Staat MA, Weinberg GA, Hall CB, Chappell J, Bernstein DI, Curns AT, Wikswo M, Shirley SH, Hall AJ, Lopman B, Parashar UD. Norovirus and medically attended gastroenteritis in U.S. children. N Engl J Med. 2013; 368:1121-1130. [PubMed: 23514289]

Perdue KA, Green KY, Copeland M, Barron E, Mandel M, Faucette LJ, Williams EM, Sosnovtsev SV, Elkins WR, Ward JM. Naturally occurring murine norovirus infection in a large research institution. J Am Assoc Lab Anim Sci. 2007; 46:39-45. [PubMed: 17645294]

Pringle K, Lopman B, Vega E, Vinje J, Parashar UD, Hall AJ. Noroviruses: Epidemiology, immunity and prospects for prevention. Future Microbiol. 2015; 10:53-67. [PubMed: 25598337]

Robinson CM, Jesudhasan PR, Pfeiffer JK. Bacterial lipopolysaccharide binding enhances virion stability and promotes environmental fitness of an enteric virus. Cell Host Microbe. 2014; 15:3646. [PubMed: 24439896]

Rockx B, de Wit M, Vennema H, Vinjé J, de Bruin E, van Duynhoven Y, Koopmans M. Natural History of Human Calicivirus Infection: A Prospective Cohort Study. Clin Infect Dis. 2002; 35:246-253. [PubMed: 12115089]

Roth AN, Karst SM. Norovirus mechanisms of immune antagonism. Curr Opin Virol. 2016; 16:24-30. [PubMed: 26673810]

Ruvoën-Clouet N, Belliot G, Le Pendu J. Noroviruses and histo-blood groups: The impact of common host genetic polymorphisms on virus transmission and evolution. Rev Med Virol. 2013; 23:355366. [PubMed: 23959967]

Sharp TM, Estes MK. An inside job: Subversion of the host secretory pathway by intestinal pathogens. Curr Opin Infect Dis. 2010; 23:464-469. [PubMed: 20717028]

Souza M, Azevedo MSP, Jung K, Cheetham S, Saif LJ. Pathogenesis and immune responses in gnotobiotic calves after infection with the genogroup II.4-HS66 strain of human norovirus. J Virol. 2008; 82:1777-1786. [PubMed: 18045944]

Swanstrom J, Lindesmith LC, Donaldson EF, Yount B, Baric RS. Characterization of blockade antibody responses in GII.2.1976 SMV infected subjects. J Virol. 2013; 88:829-837. [PubMed: 24173225]

Taube S, Kolawole AO, Höhne M, Wilkinson JE, Handley SA, Perry JW, Thackray LB, Akkina R, Wobus CE. A mouse model for human norovirus. mBio. 2013; 4:e00450-13. [PubMed: 23860770]

Teunis PFM, Sukhrie FHA, Vennema H, Bogerman J, Beersma MFC, Koopmans MPG. Shedding of norovirus in symptomatic and asymptomatic infections. Epidemiol Infect First View. 2015; 143:1710-1717.

Thackray LB, Wobus CE, Chachu KA, Liu B, Alegre ER, Henderson KS, Kelley ST, Virgin HW. Murine noroviruses comprising a single genogroup exhibit biological diversity despite limited sequence divergence. J Virol. 2007; 81:10460-10473. [PubMed: 17652401]

Thorne LG, Goodfellow IG. Norovirus gene expression and replication. J Gen Virol. 2013; 95:278291. [PubMed: 24243731] 
Tomov VT, Osborne LC, Dolfi DV, Sonnenberg GF, Monticelli LA, Mansfield K, Virgin HW, Artis D, Wherry EJ. Persistent enteric murine norovirus infection is associated with functionally suboptimal virus-specific CD8 T cell responses. J Virol. 2013; 87:7015-7031. [PubMed: 23596300]

Uchiyama R, Chassaing B, Zhang B, Gewirtz AT. Antibiotic treatment suppresses rotavirus infection and enhances specific humoral immunity. J Infect Dis. 2014; 210:171-182. [PubMed: 24436449]

Venkataram Prasad B, Shanker S, Hu L, Choi J-M, Crawford SE, Ramani S, Czako R, Atmar RL, Estes MK. Structural basis of glycan interaction in gastroenteric viral pathogens. Curr Opin Virol. 2014; 7:119-127. [PubMed: 25073118]

Ward JM, Wobus CE, Thackray LB, Erexson CR, Faucette LJ, Belliot G, Barron EL, Sosnovtsev SV, Green KY. Pathology of immunodeficient mice with naturally occurring murine norovirus infection. Toxicol Pathol. 2006; 34:708-715. [PubMed: 17074739]

Wikswo ME, Kambhampati A, Shioda K, Walsh KA, Bowen A, Hall AJ. Outbreaks of acute gastroenteritis transmitted by person-to-person contact, environmental contamination, and unknown modes of transmission-United States, 2009-2013. MMWR Morb Mortal Wkly Rep. 2015; 64:1-16. [PubMed: 25590678]

Wilks J, Lien E, Jacobson AN, Fischbach MA, Qureshi N, Chervonsky AV, Golovkina TV. Mammalian lipopolysaccharide receptors incorporated into the retroviral envelope augment virus transmission. Cell Host Microbe. 2015; 18:456-462. [PubMed: 26468748]

Wobus CE, Karst SM, Thackray LB, Chang K-O, Sosnovtsev SV, Belliot G, Krug A, Mackenzie JM, Green KY, Virgin HW. Replication of norovirus in cell culture reveals a tropism for dendritic cells and macrophages. PLoS Biol. 2004; 2:e432. [PubMed: 15562321]

Wyatt RG, Greenberg HB, Dalgard DW, Allen WP, Sly DL, Thornhill TS, Chanock RM, Kapikian AZ. Experimental infection of chimpanzees with the Norwalk agent of epidemic viral gastroenteritis. J Med Virol. 1978; 2:89-96. [PubMed: 97364]

Zhu S, Regev D, Watanabe M, Hickman D, Moussatche N, Jesus DM, Kahan SM, Napthine S, Brierley I, Hunter RN, Devabhaktuni D, Jones MK, Karst SM. Identification of immune and viral correlates of norovirus protective immunity through comparative study of intra-cluster norovirus strains. PLoS Pathog. 2013; 9:e1003592. [PubMed: 24039576]

Zhu S, Watanabe M, Kirkpatrick E, Murray AB, Sok R, Karst SM. Regulation of norovirus virulence by the VP1 protruding domain correlates with B cell infection efficiency. J Virol JVI. 2015:0288002915. 


\section{TABLE I}

The State of the Field Pertaining to Norovirus Cell Tropism

\begin{tabular}{|c|c|c|c|c|}
\hline Virus & Macrophage $(M \varphi)$ infection & Dendritic cell(DC) infection & $B$ cell infection & Enterocyte infection \\
\hline \multicolumn{5}{|l|}{$\begin{array}{l}\text { Evidence for in vitro } \\
\text { infection }\end{array}$} \\
\hline Murine norovirus & $\begin{array}{l}\text { - Multiple cell lines } \\
\text { - Primary cells }\end{array}$ & - Primary cells & $\begin{array}{l}\text { - Multiple cell lines } \\
\text { - Multiple cell lines }\end{array}$ & ND \\
\hline Human norovirus & ND & ND & & ND \\
\hline \multicolumn{5}{|l|}{$\begin{array}{l}\text { Evidence for in vivo } \\
\text { infection }\end{array}$} \\
\hline Murine norovirus & - Viral antigen in mice & $\begin{array}{l}\text { - Viral antigen in mice } \\
\text { - Reduced virus titers in DC- } \\
\text { depleted mice }\end{array}$ & $\begin{array}{l}\text { - Viral antigen in mice } \\
\text { - Reduced virus titers in B } \\
\text { cell-deficient } \\
\text { mice }\end{array}$ & $\begin{array}{l}\text { - Viral antigen in IFN- } \\
\text { deficient mice }\end{array}$ \\
\hline Human norovirus & $\begin{array}{l}\text { - Viral antigen in: } \\
\text { (i) Human intestinal } \\
\text { biopsy } \\
\text { (ii) Intestinal lamina } \\
\text { propria of calves } \\
\text { (iii) Spleen and liver of } \\
\text { mice }\end{array}$ & $\begin{array}{l}\text { - Viral antigen in duodenum } \\
\text { of chimpanzees }\end{array}$ & $\begin{array}{l}\text { - Viral antigen in } \\
\text { duodenum of } \\
\text { chimpanzees } \\
\text { - Reduced titers of shed } \\
\text { virus in B cell- } \\
\text { deficient SCID patients }\end{array}$ & $\begin{array}{l}\text { - Viral antigen in } \\
\text { gnotobiotic pigs } \\
\text { - Viral antigen in } \\
\text { gnotobiotic calves }\end{array}$ \\
\hline \multicolumn{5}{|c|}{$\begin{array}{l}\text { Evidence for persistent } \\
\text { infection }\end{array}$} \\
\hline Murine norovirus & N/A & N/A & Persistence in B cell lines & N/A \\
\hline Human norovirus & N/A & N/A & ND & N/A \\
\hline
\end{tabular}

ND, not detected, but has been examined; N/A, no examination has been reported.

References for information outlined in the table are included in the corresponding text. 